\title{
Analysis of synanthropic vegetation in the territory of the city of Ostrava
}

\author{
Marie Opálková \& Š́rka Cimalová
}

Analysis of synanthropic vegetation in the territory of the city of Ostrava.- Čas. Slez. Muz. Opava (A), 60: 201-212, 2011.

\begin{abstract}
This paper is a result of the field research of synanthropic vegetation in the territory of the city of Ostrava in the summer of 2010 (June - August) and in the spring of 2011 (April). A total of 213 reléves were carried out in three types of habitats (borders of fields, ruderal areas and railway tracks). The reléves were transferred to the 'Turboveg' database computer programme and analyzed using the Expert system of vegetation of the Czech Republic (the 'Coctail' method) in the 'Juice' computer programme. This paper contains the evaluation of the occurrence of plant species in particular habitats and of the types of their synanthropy with special regard to endangered and invasive species. A total of 201 species of vascular plants were found, among them 134 apophytes. A total of 4 endangered species and 8 invasive species were found. A total of 5 classes, 15 alliances and 25 associations were found using the analysis of vegetation in the 'Juice' computer programme. Only 5 associations occurred in all studied types of habitats. The most common association was Convolvulo arvensis-Elytrigietum repentis.
\end{abstract}

Keywords: synanthropic vegetation, Ostrava, borders of fields, ruderal areas, railway tracks, hemicryptophyte, therophyte, apophyte, archaeophyte, neophyte, Turboveg, Juice

\section{Introduction}

The existence of synanthropic communities depends on human activity. These communities can be found in artificial ecotopes and are adapted to permanent disturbing interferences. A high proportion of nitrophilous species and of species, which are disseminated thanks to human activity, is characteristic of synanthropic vegetation. This vegetation contains not only archaeophytes and neophytes, but also domestic species of flora, which respond positively to increased intensity of solar radiation, excess nutrients (especially nitrogen and phosphorus) and endure mechanical interventions. Plant species with high production of seeds, that are capable of germination even after many years and species with intensive vegetative reproduction are especially important in these habitats. The two most important ways of spreading of diasporas are zoochory and anthropochory. The origin of synanthropic communities is very diverse, but many of them come from warmer areas. The largest part of synanthropic vegetation is formed by members of the families Apiaceae, Asteraceae, Chenopodiaceae, Lamiaceae and Polygonaceae. The commonly observed monodominant vegetation shows annual periodicity, which is caused by seasonal occurrence of species or by periodic anthropogenic disturbances. At present, this type of vegetation tends to spread worldwide (Neuhäusl 1988).

The study of synanthropic vegetation had been neglected compared to the vegetation of natural habitats for a long time, but in the 1930s and 1940s, the basic concept of synanthropic vegetation in Europe was established by Josias Braun-Blanquet and Reinhold Tüxen (BraunBlanquet et al. 1936, Tüxen 1950). The first comprehensive studies of European urban vegetation were published in the 1970s. In Bohemia, Moravia and the Czech part of Silesia, the following cities were studied: Bechyně (Hadač 1982), Brno (Grüll 1979, 1981, 1982), Prague (Kopecký 1980 to 1984, Pyšek P. \& Pyšek A. 1988), Plzeň (Pyšek A. 1974, 1977). The issue of ruderal vegetation of the Ostrava region was studied by V. Kneblová (1956), Z. Kilián (Kilián \& Krkavec 1961, 1962), J. Duda (1987), R. Višňák (1995, 1996) and V. Sobotková, who studied both the synanthropic vegetation of Ostrava as a whole (Sobotková 1995) and the vegetation of mine dumps (Sobotková 1998a, 1998b). The vegetation of mine 
dumps in the Ostrava region was also studied by V. Kroutilík (1954), J. Šmarda (1964a, 1964b), M. Havrlant (Havrlant et al. 1967, Havrlant 1980), Z. Kilián (1968, 1972), B. Stalmachová (1994; Holinková \& Stalmachová 2001), V. Koutecká and T. Koutecký (Koutecká \& Koutecký 2006), K. Filipová (2007) and T. Koutecký and K. Filipová (2008). Z. Kilián (1960) engaged in the study of flora of railroads in the Ostrava region too. Weed vegetation on fields was processed in the broader context of northern Moravia and Silesia by Š. Cimalová and Z. Lososová (Cimalová 2006, Cimalová \& Lososová 2009).

Plant communities of synanthropic vegetation vary according to different types of habitats and their ecological factors, mainly by the level of disturbance and by other stress factors mentioned bellow.

Ruderal areas are located in artificially created places, which are no longer being used, e.g. rubbles, waste dumps, mine dumps, heaps, ruins, road embankments etc. They appear on ruderal, trapled and contaminated soils and on embankments. Increased concentration of nitrogen in the soil can be observed, resulting in the occurrence of nitrophilous plant species (Krippelová 1972). Typically, there are early successional stages with plant species with wide ecological valence (Begon et al. 1997).

Railway tracks are habitats that are directly related to human activities and are exposed to regular disturbances in the form of mechanical disruption and chemical stress. They offer a varied combination of different habitat characteristics and are thus attractive for various local plants. Tracks are also colonized by domestic species with wide ecological valences (Kováŕ 2005). These habitats are formed by embankment soils (Krippelová 1972).

Fields are specific habitats with mostly one-year vegetation differing by crop type and its management. Root crops used to be disturbed continuously during vegetation period in the traditional agriculture while cereals are disturbed only at sowing and at harvesting. Root crop weeds are able to regenerate fast after disturbance (Ellenberg 1988; Lososová et al. 2006) so here we can find vegetatively-reproducing species (Lamium album, Malva neglecta) and short-living species (Bromus hordeaceus, Galinsoga quadriradiata, G. parviflora). Cereal weeds are often summer therophytes (Aphanes arvensis, Matricaria discoidea) (Cimalová \& Lososová 2009).

Borders of fields are the transitional habitats between fields and roads. They are located at the borders of cultivated and trampled soils (Krippelová 1972). They can be characterized by an increased proportion of nutrients, if the fields are fertilized, some may be more humid. The species of trampled habitats (eg. Lolium perenne, Poa апnua) appear here, as well as some weed species (Anagallis arvensis, Anthemis arvensis), which appear mainly at the edges of cultures (herbicides are mainly used in the central parts of fields and weeds move into fringe communities). The original species of the landscape, which show the expansive tendencies, such as Calamagrostis epigejos, Artemisia vulgaris, Elytrigia repens (Pyšek et al. 2003) can be also found here.

The objectives of this research were to evaluate the conditions of synanthropic vegetation across selected secondary habitats in the city of Ostrava, to establish the links between communities and habitat types, to analyze the composition of vegetation according to the origin of plant species and to evaluate the occurrence of protected and invasive plant species.

\section{Material and methods}

In the summer of 2010 (July and August) and in the spring of 2011 (April) the floristic and phytosociological research was conducted in the city of Ostrava in selected secondary habitats - edges of fields, ruderal areas and railroad tracks. The last mentioned habitat was studied mainly in the Ostrava city (56 localities) and partly also in municipalities in the close surroundings (Hlučín, Darkovičky, Polanka nad Odrou, Šenov, Vratimov) (10 localities). The summer collecting of all data was performed on 120 localities. In the spring, the study was repeated only in 93 localities (because of changes in the localities and weather reasons). The localities, 
which were used for making reléves, were chosen randomly from pre-selected sites, depending on the condition of the vegetation at the time of the survey. A total of 213 reléves were recorded following the principles of the Zurich-Montpellier school (Moravec et al. 1994). The size of the area is the same for all reléves $-20 \mathrm{~m}^{2}$. This size was chosen, because in our case all of the reléves had the shape of a 10x2 m rectangle, even though the standard reléve size for Central Europe for the ruderal habitat is $16 \mathrm{~m}^{2}$ (Chytrý \& Otýpková 2003). Foliage cover is determined for each plant species in all reléves using the seven-level Braun-Blanquet cover scale (Moravec et al. 1994). The nomenclature of plant species was standardized according to Kubát et al. (2002), the nomenclature of vegetation communities was standardized according to Chytrý $(2007,2009)$. The type of synanthropy was looked up for each recorded plant species (Grüll 1979 and Pyšek et al. 2002). The constancy of all species was calculated as a percentage overall and separately for each habitat (Moravec et al. 1994). A risk category for the endangered species was looked up - both for the Czech Republic (Procházka 2001) and for the MoravianSilesian Region (Sedláčková \& Plášek 2005). The invasive species were identified according to the Catalogue of Alien Plants of the Czech Republic (Pyšek et al. 2002). The data were transferred into the 'Turboveg' database computer programme (Hennekens \& Schaminée 2001) and were subsequently analyzed by the Expert system in the 'Juice' computer program (Tichý 2002). The links between the habitat type and plant communities were then evaluated based on the frequency of the occurrence of plant communities. In the habitat of railroad tracks the plant communities were evaluated in relation to whether or not the tracks were currently being used.

\section{Study area and vegetation characteristics}

Ostrava is located in the northeastern part of the Czech Republic in the Ostrava Basin at the intersection of two major provinces - the Bohemian Massif and the Western Carpathians. The average altitude of Ostrava is 244 metres above sea level, the nature of the landscape ranges from flat to hilly. The Ostrava region belongs to the moderately warm climate area. The territory was greatly influenced by industrial emissions, but the situation has improved after 1992 (Weissmannová 2004). From the perspective of phytogeography, the territory belongs to the mesophyticum. Its potential natural vegetation consists of floodplain forests, lime-oak-hornbeam forests and wood-rush-oak and /or fir-oak forests. The forest coverage area is $10 \%$, the oak-beech forest vegetation stage is predominant (Neuhäuslová 1998).

\section{Results}

During the mapping of the three types of anthropogenic habitats a total of 213 reléves were recorded, in which a total of 201 species of vascular plants were found, of which 179 were found in the summer and 86 were found in the spring. The species constancy was calculated separately for each habitat and it is given as a percentage (Table 1 shows 20 plant species with the highest constancy). The following species had the highest constancy: Achillea millefolium, Artemisia vulgaris, Arrhenatherum elatius, Crepis biennis, Poa pratensis, Taraxacum sect. Ruderalia and Urtica dioica. The plant species belong to 42 families in total, of which the most represented families were Asteraceae (34 species), Poaceae (32 species) and Fabaceae (14 species).

A total of 113 species of plants were recorded on the borders of fields. In comparison to other habitats, plant species of trampled habitats (Lolium perenne, Plantago major, Polygonum arenastrum) and field weeds (Anagallis arvensis, Geranium dissectum, Euphorbia helioscopia) occurred here more frequently. Ruderal areas hosted 124 plant species and were rich in species with wide ecological valence, often expansive species (Artemisia vulgaris, Calamagrostis epigejos, Elytrigia repens) or invasive species (Conyza canadensis, Erigeron annuus, Solidago canadensis). On the railroad tracks, a total of 127 plant species were recorded, and unlike other habitat types, plant species of dry porous soils, such as Berteroa incana, Echium vulgare, Linaria vulgaris, Poa compressa, Reseda lutea, were recorded here.

A total of 4 protected plant species were recorded - Equisetum ramosissimum (the degree of threat for the Czech Republic (CR) - C3, the degree of threat for the Moravian-Silesian Region (MSR) - C1), Epilobium dodonaei (CR - C4a, MSR - C4), Centaurea cyanus (CR C4a, MSR - C4), Potentilla recta (CR - C4a, MSR - C4).

The invasive species (according to Pyšek et al. 2002) with the highest constancy were Conyza canadensis, Erigeron annuus and Solidago canadensis. Other invasive plants found 
during this study were Amaranthus retroflexus, Galinsoga parviflora, Impatiens parviflora, Partenocissus inserta, Reynoutria japonica.

The recorded reléves were analyzed and the vegetation units were established with the 'Cocktail' method using the full version of the Expert system for non-forest vegetation (Expertní systém vegetace ČR [online]) in the 'Juice' computer program (Tichý 2002). 5 classes, 15 alliances and 25 associations were found. In the summer collection 21 associations were found and the most reléves belonged to the following associations: Convolvulo arvensis-Elytrigietum repentis (29 reléves), Pastinaco sativae-Arrhenatheretum elatioris (22 reléves) and Rudbeckio laciniatae-Solidaginetum canadensis (13 reléves). The communities, which were recorded only in the summer months, included nine associations (Table 2). In the spring collection 16 associations were found and the most reléves belonged to the following associations: Poëtum annuae (24 reléves), Convolvulo arvensis-Elytrigietum repentis (15 reléves) and Rudbeckio laciniatae-Solidaginetum canadensis (13 reléves). The communities, which were recorded only in the spring months, included four associations (Table 2). The graphical representation of the occurrence of the associations depending on the season is shown in Figure 1 (summer data collection) and Figure 2 (spring data collection).

A total of 18 associations occurred in only one type of habitat. Table 1 shows the representation of all associations within each habitat. The analysis did not include 10 reléves with monodominant communities (with Partenocissus inserta - 1 reléve, with Arrhenatherum elatius - 4 reléves, with Dactylis glomerata - 4 reléves and with Erigeron annuus - 1 reléve).

\section{Discussion}

According to the map of reconstructed natural vegetation (Mikyška 1968-1972) or to the map of potential natural vegetation (Neuhäuslová 1998) a forest vegetation would be dominant in the Ostrava region, but for reasons of strong anthropogenic influence this type of vegetation is present only in fragments and secondary habitats are dominant. These habitats create unusual and extreme habitat conditions (Višň́k 1995) and typically accommodate nutrient-demanding species, which are resistant to disturbances and are competitively strong. Secondary habitats are also characterized by considerable diversity (Sádlo \& Storch 2000).

The archaeophytes are much more numerous than neophytes, as demonstrated by Simonová \& Lososová (2008). This preponderance is due to the fact that archaeophytes have existed for a long time in this country and they are better adapted to local conditions than neophytes, which usually occur only sporadically. Paradoxically, the list of all plants of the Czech Republic mentions 332 archaeophytes and 1046 neophytes, even though archaeophytes are more frequent in the reléve. It can be explained by the fact that 748 neophyte taxa are recorded only rarely (Pyšek et al. 2002).

The neophytes are potentially dangerous for our country, because they can start to spread uncontrollably and thus threaten native communities. A total of 90 invasive plant species occur in the Czech Republic, of which 69 belong to the neophytes (Pyšek et al. 2002). The most common neophyte in our study was Solidago canadensis. A problematic neophyte of the localities with higher moisture and nutrient content is Reynoutria japonica, which, for example on the banks of the Odra River in Ostrava - Petrrkovice, creates large, up to two metres high monodominant stands (Ševčík et al. 2005). This type of habitat was not a part of the current research, and therefore the frequency of occurrence of this species is low in the data set.

Not only alien species are spreading in the landscape, there are also the native - expansive - species. They have specific characteristics allowing them to spread quickly and easily, such as the ability of vegetative spreading, production of large quantities of generative diasporas, 
Tab. 1: Species constancy (percentage). Calculation for the summer data set. Explanation of abbreviations: b.f. $=$ borders of fields; r.a. $=$ ruderal areas; r.t. $=$ railroad tracks

\begin{tabular}{|l|c|c|c|}
\hline Species name & b.f. & r.a. & r.t. \\
\hline Arrhenatherum elatius & 70 & 62.5 & 52.5 \\
Achillea millefolium & 22.5 & 62.5 & 40 \\
Artemisia vulgaris & 32.5 & 52.5 & 60 \\
Calamagrostis epigejos &. & 47.5 & 45 \\
Cirsium arvense & 42.5 & 35 & 10 \\
Crepis biennis & 42.5 & 45 & 42.5 \\
Dactylis glomerata & 70 & 22.5 & 7.5 \\
Daucus carota & 5 & 30 & 22.5 \\
Elytrigia repens & 65 & 12.5 & 5 \\
Erigeron annuus &. & 52.5 & 57.5 \\
Lactuca serriola & 20 & 25 & 32.5 \\
Medicago lupulina & 5 & 32.5 & 37.5 \\
Pastinaca sativa & 2.5 & 37.5 & 42.5 \\
Plantago lanceolata & 22.5 & 32.5 & 22.5 \\
Plantago major & 20 & 27.5 & 15 \\
Poa pratensis & 75 & 40 & 15 \\
Rubus sp. & 12.5 & 7.5 & 37.5 \\
Solidago canadensis & 10 & 57.5 & 55 \\
Taraxacum sect. ruderalia & 35 & 72.5 & 70 \\
Urtica dioica & 67.5 & 37.5 & 25 \\
\hline
\end{tabular}

Tab. 2: Overview of all detected associations of all studied habitats in each collection. Explanation of abbreviations: b.f. $=$ borders of fields; r.a. = ruderal areas; r.t. = railroad tracks

\begin{tabular}{|c|c|c|c|c|c|c|c|c|}
\hline \multirow{2}{*}{ Name of association } & \multicolumn{4}{|c|}{ summer 2010 (Jul, Aug) } & \multicolumn{4}{|c|}{ spring 2011 (Apr) } \\
\hline & b.f. & r.a. & r.t. & SUM & b.f. & r.a. & r.t. & SUM \\
\hline Alliario petiolatae-Chaerophylletum temuli & & & & 0 & & & 1 & 1 \\
\hline Arctietum lappae & & 1 & & 1 & & & & 0 \\
\hline Berteroetum incanae & & & 9 & 9 & & & & 0 \\
\hline Calystegio sepium-Epilobietum hirsuti & & 1 & & 1 & & & & 0 \\
\hline Convolvulo arvensis-Elytrigietum repentis & 21 & 4 & 4 & 29 & 11 & 3 & 1 & 15 \\
\hline Conyzo canadensis-Lactucetum serriolae & & & 3 & 3 & & & & 0 \\
\hline Digitario sanguinalis-Eragrostietum minoris & & & 2 & 2 & & & & 0 \\
\hline Elytrigio repentis-Aegopodietum podagrariae & 2 & & & 2 & 1 & 6 & & 7 \\
\hline Erophilo vernae-Arabidopsietum thalianae & & & & 0 & & 1 & 1 & 2 \\
\hline Hordeo murini-Brometum sterilis & 1 & & & 1 & & & 1 & 1 \\
\hline Chaerophylletum aromatici & 1 & & & 1 & & & & 0 \\
\hline Chenopodietum stricti & & & 1 & 1 & & & & 0 \\
\hline Linario-Brometum tectorum & & & & 0 & & & 1 & 1 \\
\hline Lolietum perennis & 5 & 4 & & 9 & & 4 & 7 & 11 \\
\hline Melilotetum albo-officinalis & & 2 & & 2 & & & & 0 \\
\hline Pastinaco sativae-Arrhenatheretum elatioris & 4 & 13 & 5 & 22 & 4 & 2 & & 6 \\
\hline Poёtum annuae & & & 1 & 1 & 5 & 10 & 9 & 24 \\
\hline Poëtum humili-compressae & & & 3 & 3 & & & 1 & 1 \\
\hline Polygonetum arenastri & & & 1 & 1 & & 2 & & 2 \\
\hline Reynoutrietum japonicae & & & 1 & 1 & & 1 & & 1 \\
\hline Rudbeckio laciniatae-Solidaginetum canadensis & 1 & 8 & 4 & 13 & & 5 & 8 & 13 \\
\hline Symphyto officinalis-Anthriscetum sylvestris & 2 & & & 2 & 2 & & & 2 \\
\hline Tanaceto vulgaris-Artemisietum vulgaris & 1 & 4 & 2 & 7 & & 1 & & 1 \\
\hline Veronicetum hederifolio-triphylli & & & & 0 & 1 & & & 1 \\
\hline Veronico-Lamietum hybridi & 2 & & & 2 & & & & 0 \\
\hline
\end{tabular}


the ability of diasporas to spread in space and time, the ability of seeds to germinate in a wide range of conditions and the ability to regenerate after a disturbance (Pyšek et al. 2003). In this study, we recorded the following expansive species: Artemisia vulgaris, Calamagrostis epigejos, Elytrigia repens and Urtica dioica. These species were often dominant in the vegetation.

The secondary habitats provide favourable conditions for endangered plants (e.g. Ševčík et al. 2008, Simonová 2007). These habitats are usually characterized by an extreme factor temperature or water regime, nutrient content etc. For example, Epilobium dodonaei naturally occurs on sunny localities of drying sandy and gravel substrates, but in the industrial landscape, it grows on railway embankments, railway stations, in quarries, sandpits and gravel-pits and also on mine dumps. The properties of these habitats are closely related to the original habitats (Smejkal 1997).

The analysis of vegetation of the studied habitats revealed a total of 5 classes, 15 alliances and 25 associations. The class Polygono arenastri-Poëtea annuae consists of annual ruderal vegetation that develops at stands exposed to trampling. This is the initial successional stage (Chytrý 2009). A total of 3 associations belonged to this class. Polygonetum arenastri and Poëtum annuae occurred only in the habitat of railroad tracks, exclusively on the currently used tracks in the summer collection. In the spring collection the first association occurred only in ruderal areas and the second occurred in all types of habitats. The association Veronicetum hederifolio-triphylii is a spring ephemeral community of field weeds on loamy soils. The communities of this class are adapted to permanent disturbances and can therefore thrive on these habitats.

The class Stellarietea mediae consists of annual vegetation that develops on disturbed stands. Both segetal and ruderal vegetation belong to this class and also constitute the initial stages of succession (Chytrý 2009). A total of 7 associations belonged to this class: a weed vegetation of crops with Anagallis arvensis and Euphorbia helioscopia (the association Veronico-Lamietum hybridi), which occurred exclusively on borders of fields; the association Erophilo vernae-Arabidopsietum thalianae, which commonly occurs on acidic soils in the spring and in our research it was found in ruderal areas and near railway tracks; a community with Chenopodium album agg. (the association Chenopodietum stricti), which was found only on unused rail tracks near a station; the association Conyzo canadensis-Lactucetum serriolae, which occurred only on railway tracks on embankments; species-poor community of Bromus sterilis (the association Hordeo murini-Brometum sterilis), which was found only on one locality on a border of a field; the association Linario-Brometum tectorum was found on an embankment of used tracks only in the spring collection; the community with low-growing grasses (the association Digitario sanguinalis-Eragrostietum minoris) occurred only in the habitat of unused railway tracks.

The class Artemisietea vulgaris consists of the xerophilic and relatively thermophilous vegetation of anthropogenic habitats, which is dominated by biennial or perennial species. It is a nitrophilous vegetation, habitats are usually sunny with dry soils. During secondary succession it replaces the class Stellarietea mediae (Chytrý 2009). A total of 7 associations belonged to this class: the community with Melilotus album (the association Melilotetum albo-officinalis), which occurred only in the habitat of ruderal areas; the association Berteroetum incanae, which occurred only on the habitat of railway tracks, and it was the most represented association in this habitat in the summer collection (9 localities). It was found on the embankments of used tracks. The association Poëtum humili-compressae is the xerophyte vegetation of tracks and quarries with shallow soils. It was also found only on used railroad tracks. Again, it was recorded on the embankments of used tracks. The association Tanaceto vulgaris-Artemisietum vulgaris consists of tall vegetation of hemicryptophytes and it was represented in all habitat types, as well as the association Rudbeckio laciniatae- 
Solidaginetum canadensis, which consists of invasive plant species such as Solidago canadensis. The next association of this class is Convolvulo arvensis-Elytrigietum repentis, which was represented in the largest number of reléves, again in all types of habitats. This species-poor community occurs on the borders of fields, in ditches, roadsides and highways. The last association of this class is Arctietum lappae, which was found only once in the habitat of ruderal areas.

The class Galio-Urticetea contains the nitrophilous perennial vegetation, which occurred on mesic to wet habitats. The broad-leaved herbs (e.g. Aegopodium podagraria, Chaerophyllum aromaticum, Urtica dioica) and grasses (Dactylis glomerata, Elytrigia repens) occur in this vegetation. These communities occur in the form of fringe vegetation that is usually species-poor and often has a single dominant species. In comparison to other types of ruderal vegetation, this class hosts the largest average proportion of indigenous species (Chytrý 2009). A total of 6 associations belonged to this class: the community with Epilobium hirsutum (the association Calystegio sepium-Epilobietum hirsuti), which occurred in moist habitats with fluctuating water regime. This association was observed only once in the habitat of ruderal areas. The association Alliario petiolatae-Chaerophylletum temuli belongs to nitrophilous fringe communities and it was found once in the habitat of tracks in the spring data collection. The community with Aegopodium podagraria (the association Elytrigio repentis-Aegopodietum podagrariae) occurred on the more humid localities twice in the habitat of borders of fields in the summer data collection, it was also found in the habitat of ruderal areas in the spring data collection. The association Symphyto officinalisAnthriscetum sylvestris typically consists of Anthriscus sylvestris and Urtica dioica along with other broad-leaved and nitrophilous herbs and grasses. It was reported in the habitat of borders of fields. The association Chaerophylletum aromatici was found in one locality in the habitat of borders of fields. The last association of this class is Reynoutrietum japonicae with invasive Reynoutria japonica. It occurred at one locality in the habitat of tracks and at one locality in the habitat of ruderal areas.

The last determined class is Molinio-Arrhenatheretea, that includes vegetation of meadows and pastures in the mesic and humid, nutrient-rich soils. The character of its communities is indicated by the presence of perennial grasses and eudicot herbs, which usually form heavily involved, often species-rich vegetation (Chytrý 2007). The association of Pastinaco sativaeArrhenatheretum elatioris was determined at 28 localities of all three habitat types, and it is the second most represented community. Although it is typical meadow vegetation, it is represented in anthropogenic habitats in the city. It can be explain by the fact that meadow species are present in urban lawns and gardens, from where they can penetrate into adjacent anthropogenic habitats. The result is species-poorer vegetation often containing alien invasive (Cirsium arvense, Erigeron annuus, Solidago sp.) and expansive (Calamagrostis epigejos) taxa. The association Lolietum perennis typically consists of the species of trampled habitats, such as Lolium perenne and Plantago major and was recorded on 20 localities in all habitat types.

The evaluation of representation of associations in the studied habitats shows that the weed vegetation and nitrophilous hydrophilic vegetation occurred only on borders of fields along with the other types of vegetation, which occurred in all types of studied habitats. The most common association in the habitat of borders of fields was the association Convolvulo arvensis-Elytrigietum repentis. In the summer the following associations were found only in this type of habitat: Elytrigio repentis-Aegopodietum podagrariae, Hordeo murini-Brometum sterilis, Chaerophylletum aromatici, Symphyto officinalis-Anthriscetum sylvestris and Veronico-Lamietum hybridi. In the spring the following associations were found only in this type of habitat: Symphyto officinalis-Anthriscetum sylvestris and Veronicetum hederifoliotriphylli. 
The occurrence of communities in the habitat of ruderal areas depended on the water conditions of the particular habitat; the most common association of this habitat was Pastinaco sativae-Arrhenatheretum elatioris in the summer months and Poëtum annuae in the spring months. In the summer the following associations were found only in this type of habitat: Arctietum lappae, Calystegio sepium-Epilobietum hirsuti and Melilotetum alboofficinalis. In the spring the following associations were found only in this type of habitat: Polygonetum arenastri, Reynoutrietum japonicae and Tanaceto vulgaris-Artemisietum vulgaris.

The type of community in the habitat of railroad tracks depended on whether it appeared on used or abandoned tracks. The most common association in this type of habitat was Berteroetum incanae in the summer and Poëtum annuae in the spring. The following communities were recorded on the used tracks: Berteroetum incanae and Poëtum humilicompressae. On abandoned tracks and on wider embankments the following communities, which are typical of drier habitats, were found: Digitario sanguinalis-Eragrostietum minoris, Conyzo canadensis-Lactucetum serriolae and Chenopodietum stricti. On the tracks, which have not been used for a long time, common associations, which also occurred in the other two types of habitats, were found: Convolvulo arvensis-Elytrigietum repentis, Pastinaco sativae-Arrhenatheretum elatioris, Rudbeckio laciniatae-Solidaginetum canadensis. This fact indicates an advanced stage of succession on abandoned tracks. In the summer the following associations were recorded only in this type of habitat: Berteroetum incanae, Conyzo canadensis-Lactucetum serriolae, Digitario sanguinalis-Eragrostietum minoris and Chenopodietum stricti. In the spring the following associations were recorded only in this type of habitat: Alliario petiolatae-Chaerophylletum temuli, Hordeo murini-Brometum sterilis, Linario-Brometum tectorum and Poëtum humili-compressae.

\section{Conclusions}

During the study of synanthropic vegetation in the city of Ostrava, 201 species of vascular plants were found in three types of habitats (borders of fields, ruderal areas, railroad tracks). A total of 179 species were recorded in the summer and a total of 86 species were recorded in the spring. Most of the species belonged to the families Asteraceae and Poaceae. $65 \%$ of them belonged to the group of apophytes (Pyšek et al. 2003) in terms of type of synantropy. A total of 4 protected and endangered plant species were found (Centaurea cyanus, Epilobium dodonaei, Equisetum ramossissimum, Potentilla recta). The invasive species with the highest constancy were Conyza canadensis, Erigeron annuus, Solidago canadensis. The analysis of vegetation revealed 5 classes, 15 alliances and 25 associations, of which only 5 occurred in all three habitat types (Convolvulo arvensis-Elytrigietum repentis, Lolietum perennis, Pastinaco sativae-Arrhenatheretum elatioris, Rudbeckio laciniatae-Solidaginetum canadensis, Tanaceto vulgaris-Artemisietum vulgaris).

Acknowledgements: The first author wishes to thank Jana Fehérová, Kateřina Filipová and Daniel Křenek for their company during the recording of data and Jakub Seget for his help with the English version of this paper. 


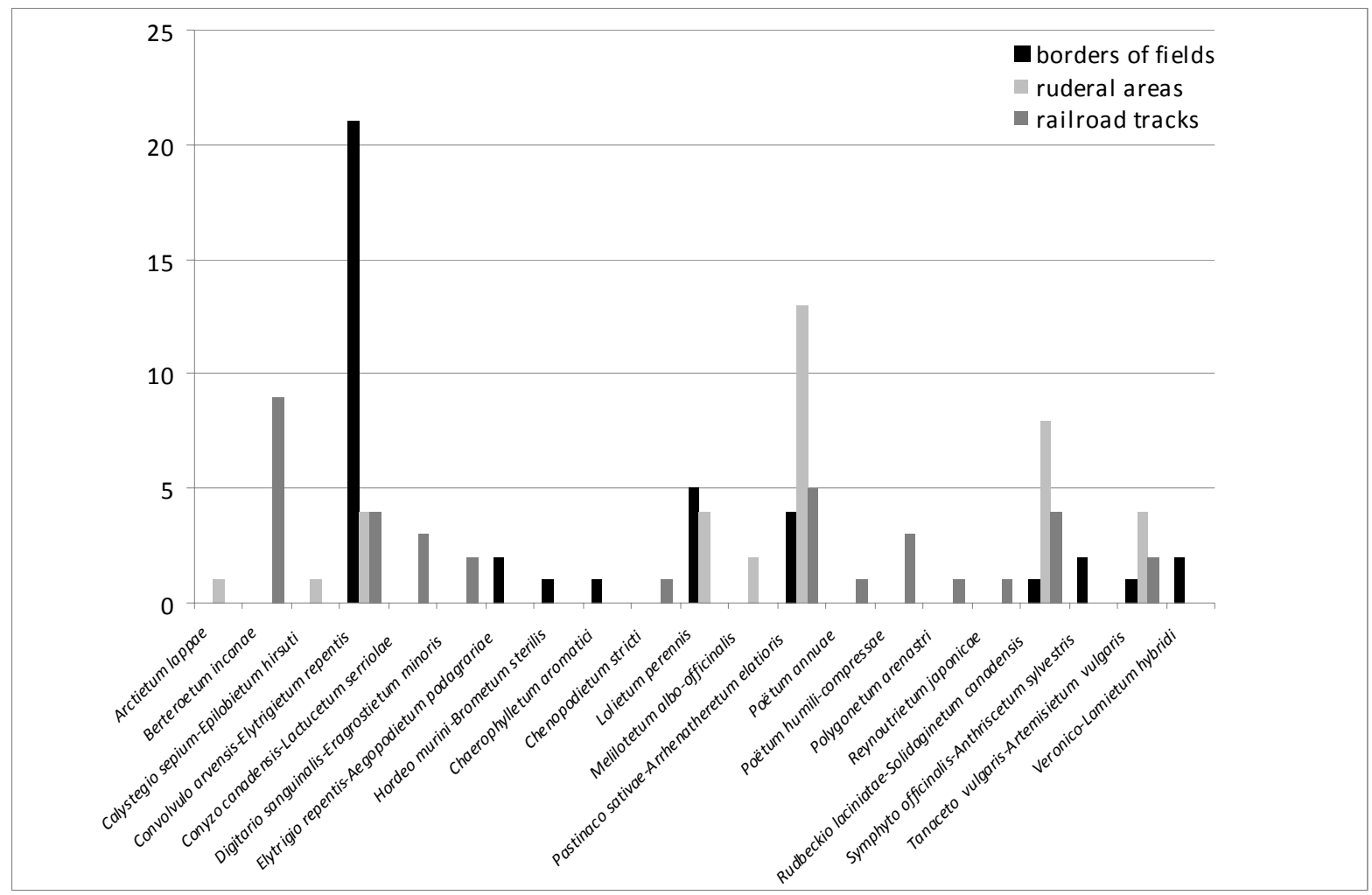

Fig. 1: Occurrence of individual associations in different habitats in the summer data collection (2010)

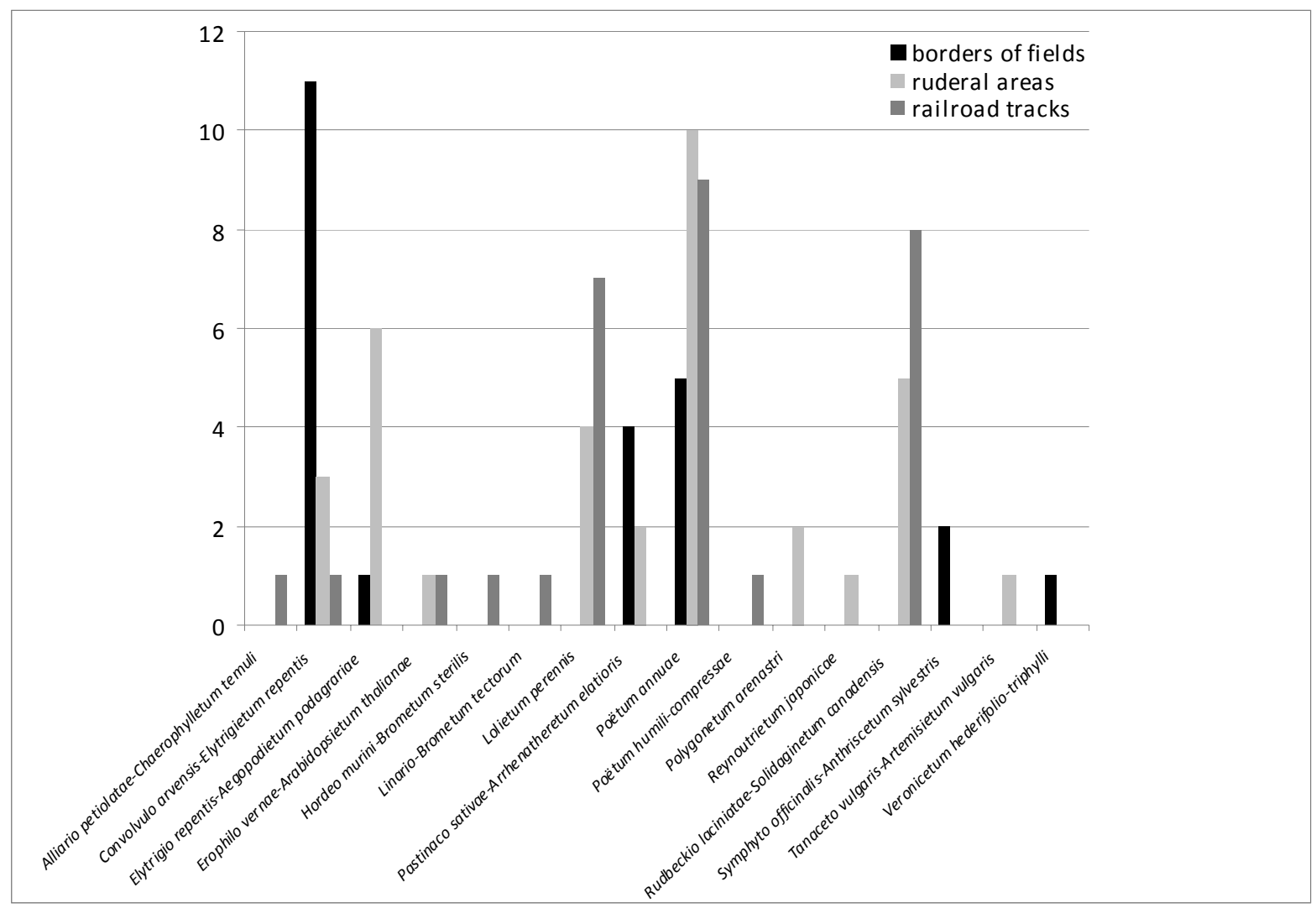

Fig. 2: Occurrence of individual associations in different habitats in the spring data collection (2011) 


\section{References}

Begon M., Harper J., Townsend CR. (1997): Ekologie. Jedinci, populace a společenstva. Vydavatelství Univerzity Palackého, Olomouc, 949 pp.

Braun-Blanquet J., Gajewski W., Wraber M. \& Walas J. (1936): Prodrome des groupements végétaux [Prodrome plant communities]. Fasc. 3. (Classe des Rudereto-Secalinetales. Groupements messicoles, culturaux et nitrophiles-rudérales du cercle de végétation méditerranéen). - Mari-Lavit, Montpellier.

Cimalová Š. (2006): Historické a recentní rozšíření vzácných druhů polních plevelů severní a stř̌ední Moravy a Slezska [Historical and recent distribution of rare weed species in northern and central Moravia and Silesia]. - Čas. Slez. Muz. Opava (A), 55: 165-192.

Cimalová Š. \& Lososová Z. (2009): Arable weed vegetation of the northeastern part of the Czech Republic: effects of environmental factors on species composition. - Plant Ecology, 203/1: 45 -57.

Duda J. (1987): Poznámky ke květeně Ostravsko-karvinského revíru [Notes on the Flora of the Ostrava Karviná district]. - Čas. Slez. Muz. Opava (A), 36: 180-192.

Ellenberg H. (1988): Vegetation Ecology of central Europe, 4th ed. - Cambridge University Press, Cambridge.

Filipová K. (2007): Výskyt druhů z červeného seznamu cévnatých rostlin na vybraných odvalech na území města Ostravy a okolí [Species of Red list of vascular plants on the selected mine dumps in Ostrava city and environs]. - Čas. Slez. Muz. Opava (A), 56: 78-82.

Grüll F. (1979): Synantropní flóra a její rozšǐření na území města Brna [Synanthropic flora and its distribution in the city of Brno]. Studie ČSAV. - Academia, Praha, 224 pp.

- (1981): Fytocenologická charakteristika ruderálních společenstev na území města Brna [Syntaxonomy overview of the ruderal communities in the city of Brno]. Studie ČSAV, 10. - Academia, Praha, 127 pp.

- (1982): Málo známá pionýrská společenstva rostlin na obnažených půdách staveništ’ města Brna [Little-known pioneer plant communities on the exposed soil of the buildings in Brno]. - Preslia, 55: 235-243.

Hadač E. (1982): Poznámky o ruderálních společenstevech města Bechyně [Notes on ruderal communities of Bechyně]. - Preslia, 54: 141-147.

Havrlant M., Kincl M. \& Gerlich V. (1967): Př́rodní podmínky a současný stav vegetačního krytu na černouhelných haldách Ostravsko - karvinského revíru [Natural conditions and the current state of vegetation cover on mine dumps in Ostrava - Karviná district]. Spisy PdF Ostrava, sv. 7. - SPN, Praha, 81 pp.

Havrlant M. (1980): Antropogenní formy reliéfu a životní prostředí v ostravské průmyslové oblasti [Anthropogenic forms of relief and the environment in the Ostrava industrial area]. Spisy PdF Ostrava, sv. 41. - SPN, Praha, 153 pp.

Hennekens S. M. \& Schaminée J. H. J. (2001): Turboveg, a comprehensive data base management systém for vegetation data. - Journal of Vegetation Science 12: 589-591.

Holinková Z. \& Stalmachová B. (2001): Vegetační poměry poklesových kotlin v dobývacím prostoru dolu František [Vegetation conditions of subsidence hollows in the mining area of "František" mine]. Hornická a podhornická krajina Horního Slezska.- VŠB-TU, Ostrava, 1: 15-17.

Chytrý M. [ed.] (2007): Vegetace České republiky 1. Travinná a keříčková vegetace [Vegetation of the Czech Republic 1. Grassland and Heathland Vegetation]. - Academia, Praha, 526 pp.

- [ed.] (2009): Vegetace České republiky 2. Ruderální, plevelová, skalní a sutová vegetace [Vegetation of the Czech Republic 2. Ruderal, Weed, Rock and Scree Vegetation]. - Academia, Praha, 520 pp.

Chytrý M. \& Otýpková Z. (2003): How large are the plots used for phytosociological sampling of European vegetation? - Journal of Vegetation Science 14: 563-570.

Kilián Z. (1960): Květena železničních tratí Ostravska [Flora of railways in Ostrava region]. - Př́rod. Čas. Slez., 21: 124-125.

- (1968): Vegetace plošiny nižší svahové haldy Dolu Trojice ve Slezské Ostravě [Vegetation platforms of lower sloped dump of the mine "Trinity" in Silesian Ostrava]. - Př́rodovědecký sborník Ostravského muzea, Ostrava, 24: 220-222.

- (1972): Př́spěvek ke květeně hald na Ostravsku [Contribution to the flora of the mine dumps in Ostrava]. Přírodovědecký sborník Ostravského muzea, Ostrava, 25: 265-266.

Kilián Z. \& Krkavec F. (1961): Floristický obraz rudišt' na Ostravsku [Floristic image of the rubble sites in Ostrava]. - Př́rod. Čas. Slez., 22: 255-264.

- (1962): Druhý př́spěvek k poznání květeny rudišt' na Ostravsku [The second contribution to the knowledge of flora of the rubble sites in Ostrava]. - Př́rod. Čas. Slez., 23: 45-50.

Kneblová V. (1956): Fytocenologický průzkum Ostravska [Phytosociological survey of Ostrava]. - Přír. Sbor. Ostrav. kraje, 17: 520-529.

Kopecký K. (1980-1984): Die Ruderalpflanzengesellschaften im südwestlichem Teil von Praha [Ruderal vegetation in the southwest part of Prague]. - Preslia, 52: 241-267; 53: 121-145; 54:67-89; 54: 123-139; 55: 289-298; 56: 55-72. 
Koutecká V. \& Koutecký T. (2006): Sukcese na antropogenních stanovištích hornické krajiny Ostravskokarvinského revíru [Succession of anthropogenic states of mining landscapes in the Ostrava - Karviná district]. - Zpr. Čes. Bot. Společ., Praha, 41, Mater. 21: 117-124.

Koutecký T. \& Filipová K. (2008): Flora and Geobiocoenoses at Coal Mine Spoil Heaps in the OstravaKarviná Coal District. In: Boltižiar M. [ed.]: Implementation of Landscape Ecology in a New Changing Conditions. Proceedings of the 14th International Symposium on Problems of Ecological Research, 4-7 October 2006, Stará Lesná, High Tatras Mts., Slovak Republic, Institute of Landscape Ecology of the Slovak Academy of Science, Bratislava, branch Nitra: 179-186.

Kovář P. (2005): K čemu jsou rostlinám dobré koleje a nádraží [For what are tracks and railway stations good for plants]. Živa, 53: 13-15.

Krippelová T. (1972): Ruderálne spoločenstvá mesta Malaciek [Ruderal communities of the city of Malacky]. - Biologické práce. Vydavatelstvo Slovenskej akadémie vied, Bratislava, 18 (1): 5-116.

Kroutilík V. (1954): Haldové pokryvy na území města Ostravy [Vegetation of the mine dumps in the city of Ostrava]. - Slezský studijní ústav, Opava, 39 pp.

Kubát K., Hrouda L., Chrtek J. jun., Kaplan Z., Kirschner J. \& Štěpánek J. (eds.) (2002): Klíč ke květeně České republiky [Key to the flora of the Czech Republic]. - Academia, Praha, 926 pp.

Láníková D. \& Lososová Z. (2009): Rocks and Walls: Natural Versus Secondary Habitats. - Folia Geobot., 44: $263-280$

Lososová Z., Chytrý M., Kühn I., Hájek O., Horáková V., Pyšek P. \& Tichý L. (2006): Patterns of plant traits in annual vegetation of man-made habitats in Central Europe. - Perspectives in Plant Ecology, Evolution and Systematics 8: 69-81.

Mikyška R. [ed.] (1968-1972): Geobotanická mapa ČSSR 1. České země. Vegetace ČSSR, ser. A, 2 [Geobotanical map of the CSSR 1. Czech country. Vegetation of the CSSR, ser. A, 2]. - Academia, Praha.

Moravec J. et al. (1994): Fytocenologie [Phytosociology]. - Academia, Praha, 403 pp.

Neuhäusl R. (1988): Rostlinstvo, pp. 36-51. In: Hejný S. \& Slavík B. [eds.]: Květena České republiky 1 [Flora of the Czech Republic 1]. - Academia, Praha, 556 pp.

Neuhäuslová Z. (1998): Mapa potenciální přirozené vegetace České republiky [Map of Potential Natural Vegetation of the Czech Republic]. - Academia, Praha, 341 pp.

Procházka F. [ed.] (2001): Černý a červený seznam cévnatých rostlin České republiky (stav v roce 2000) [Black and Red List of Vascular Plants of the Czech Republic - 2000]. - Prríroda, Praha, 18: 1-166.

Pyšek A. (1974): Kurzgefasste Übersicht der Ruderalvegetation von Plzeň und seiner nahen Umgebung [Concise Overview of ruderal vegetation of the city of Plzeň and its surroundings]. - Fol. Mus. Rer. Nat. Boh. Occid., Plzeň, 1-41.

- (1977): Sukzession der Ruderalpflanzengesellschaften von Gross-Plzeň [The succession of ruderal vegetation in Plzeň]. - Preslia, 49: 161-179.

Pyšek P. (1996): Synantropní vegetace [The synanthropic vegetation]. - VŠB-TUO and MŽP ČR, Ostrava, 90 pp.

Pyšek P. \& Pyšek A. (1988): Die Vegetation der Betriebe des östlichem Teiles von Praha. Floristische Verhältnisse [The vegetation on the farms of the eastern part of Prague. Floristic relations.]. - Preslia, 60: 339-347.

Pyšek P., Kubát K. \& Prach K. (2003): Expanzní druhy domácí flóry a apofytizace krajiny [Expansive species in the Czech flora and associated landscape changes]. - Zpr. Čes. Bot. Společ., mater. 19, Praha, 119 pp.

Pyšek P., Sádlo J. \& Mandák B. (2002): Catalogue of alien plants of the Czech Republic. - Preslia, Praha, 74: $97-186$.

Sádlo J. \& Storch D. (2000): Biologie krajiny. Biotopy České republiky [Biology of landscape. Habitats of the Czech Republic]. - Vesmír, Praha, 92 pp.

Sedláčková M. \& Plášek V. (2005): Červený seznam cévnatých rostlin Moravskoslezského kraje [Red List of Vascular Plants of the Moravian-Silesian region]. - Čas. Slez. Muz. Opava (A), 54: 97-120.

Simonová D. (2007): Zdi - sekundární stanoviště pro růst rostlin [Walls - secondary habitat for plant growth]. - Živa, Academia, LV (XCIII) (2): 62-64.

Simonová D. \& Lososová Z. (2008): Which factors determine plant invasions in man-made habitats in the Czech Republic? - Perspectives in Plant Ecology, Evolution and Systematics, 10: 89-100.

Smejkal M. (1997): Chamerion (Rafin.) Rafin. pp. 95-99. In: Slavík B. [ed.]: Květena České republiky 5 [Flora of the Czech Republic 5]. - Academia, Praha, 568 pp.

Sobotková V. (1995): Synantropní flóra a vegetace na území města Ostravy [Synanthropic flora and vegetation in the city of Ostrava]. - Scripta Fac. Rer. Nat. Univ. Ostraviensis 87: 5-73.

- (1998a): Floristický a fytocenologický výzkum odvalu Nové huti v Ostravě [Floristic and phytosociological research on the mine dump "Nová hut" in Ostrava]. - Acta Fac. Rer. Nat. Univ. Ostraviensis 165, Biologica-Ecologica (4-5): 19-31. 
- (1998b): Floristický a fytocenologický výzkum odvalu dolu Paskov [Floristic and phytosociological research on the dump of the mine "Paskov"]. - Acta Fac. Rer. Nat. Univ. Ostraviensis 165, Biologica-Ecologica (45): 33-45.

Stalmachová B. (1994): Sukcese rostlin na odvalech Ostravsko-karvinského revíru [Succession of plants on the mine dumps in Ostrava-Karviná district]. - Zpr. Čes. Bot. Společ., Praha, 29, Mater. 11: 71-76.

Ševčík J., Fasterová J. \& Tabášková K. (2008): Orchideje na odvalech v centru Ostravy [Orchids on the mine dumps in the centre of the Ostrava city]. - Živa, 56: 113.

Ševčík J., Pečinka A. \& Plášek V. (2005): Rostliny Národní přírodní památky Landek [Plants of National nature monument "Landek"]. - Biologicko-ekologický klub, Ostrava, 47 pp.

Šmarda J. (1964a): Vegetace ostravských hald [Vegetation of the mine dumps in the Ostrava city]. - Zpr. Geograf. Úst. ČSAV, Opava, 8:1-12.

- (1964b): K výzkumu vegetace ostravských hald [To research of vegetation on the mine dumps in the city of Ostrava]. - Zpr. Geograf. Úst. ČSAV, Opava, 6: 4-5

Tichý L. (2002): Juice, Software for Vegetation Classification. - Journal of Vegetation Science 13: 451-453.

Tüxen R. (1950): Grundriß einer Systematik der nitrophilen Unkrautgesellschaten in der Eurosibirischen Region Europas. - Mitt. Florist.-Soziol. Arbeitsgem., N.F.2: 94-175.

Višňák R. (1995): Synanthropic vegetation of the Ostrava city area. Part 1. - Preslia, 67 (4): 261-299.

- (1996): Synanthropic vegetation of the Ostrava city area. Part 2. - Preslia, 68 (1): 59-94.

Weissmannová H. et al. (2004): Ostravsko [The Ostrava region]. In: Mackovčin P. \& Sedláček M. [eds.]: Chráněná území ČR, sv. X. - AOPK ČR a Ekocentrum Brno, Praha, 456 pp.

\section{Analýza synantropní vegetace na území města Ostravy}

Tato práce je výsledkem terénního výzkumu synantropní vegetace na území města Ostravy v roce 2010 (červen - srpen) a 2011 (duben). Bylo zaznamenáno 213 fytocenologických snímků ve třech typech biotopů (lemy polí, ruderální plochy a železniční tratě). Práce obsahuje zhodnocení zastoupení druhů rostlin V jednotlivých biotopech, typu synantropie, zvláštní pozornost byla věnována druhům chráněným a invazním. Fytocenologické snímky byly přepsány do databázového programu Turboveg a následně byla provedena analýza vegetace Expertním systémem vegetace ČR (metoda Coctail) v programu Juice. Bylo zaznamenáno celkem 201 druhů cévnatých rostlin, z toho bylo 134 apofytů. Celkem byly zjištěny 4 chráněné druhy a 8 druhů invazních. Analýzou vegetace bylo zjištěno 5 tříd, 15 svazů a 25 asociací. Pouze 5 asociací se vyskytlo ve všech typech biotopů. Nejběžnější asociací byla Convolvulo arvensis-Elytrigietum repentis.

Authors' addresses: Marie Opálková \& Šárka Cimalová, Dept. of Biology and Ecology, Faculty of Science, University of Ostrava, Chittussiho 10, CZ-710 00, Ostrava, Czech Republic; e-mail: opalkovamarie@seznam.cz, sarka.cimalova@osu.cz 